\title{
Actualization of Pancasila Values in The Tahlilan Tradition in Sapen Village Yogyakarta
}

\author{
Lukman Fajariyah*, Mohammad Dzulkifli** \\ *Mahasiswa Interdisciplinary Islamic Studies Pascasarjana UIN Sunan Kalijaga Yogyakarta. Email: \\ lukmanfajar9@gmail.com, ${ }^{* *}$ Mahasiswa Magister Fakultas Adab dan Ilmu Budaya UIN Sunan Kalijaga \\ Yogyakarta. Email: dzulkifli976@gmail.com
}

\begin{abstract}
This study aims to describe how Pancasila values are implanted in the tahlilan tradition in Kampung Sapen Yogyakarta. This study employs a qualitative descriptive method using interviews with several figures in Kampung Sapen. The study finds that the tahlilan tradition among Sapen community enables to instill Pancasila values, including: 1) theological awareness of the existence of God Who Creates and Destroys; this is the practice of Divine values/the first pillar; 2) the expression of sympathy for the bereaved family, and a congregational prayer for the deceased; this is the practice of the second pillar; 3) the gatherings that reflect a sense of brotherhood and unity/the third pillar; 4) a full obedience to the leader of tahlil can be seen as the practice of the fourth pillar; 5) Equality of seats, food and duties shows the practice of justice within the community. Tahlilan in Kampung Sapen has been practiced since the 1950s. For the people of Sapen, tahlilan plays as a hub of friendship and da'wah.
\end{abstract}

Keywords: Pancasila values, tahlilan, Sapen

\section{Aktualisasi Nilai-Nilai Pancasila dalam Tradisi Tahlilan di Kampung Sapen Yogyakarta}

\begin{abstract}
Abstrak
Penelitian ini bertujuan untuk mendeskripsikan representasi nilai-nilai Pancasila dalam tradisi tahlilan di Kampung Sapen Yogyakarta. Penelitian ini menggunakan metode deskriptif kualitatif dengan teknik wawancara terhadap beberapa tokoh dari penduduk Sapen yang representatif. Hasil penelitian ini menunjukkan bahwa dalam tradisi tahlilan terdapat pengamalan nilai-nilai Pancasila yang selama ini dipraktikkan oleh masyarakat, yaitu: 1) kesadaran teologi akan adanya Tuhan yang Maha Menciptakan dan Mematikan manusia dan seluruh makhluk-makhluknya, ini adalah pengamalan dari nilai ketuhanan; 2) adanya simpati pada keluarga yang berduka, dan doa bersama untuk meminta kebaikan untuk sang almarhum, adalah pengamalan sila kedua; 3) berkumpulnya semua lapisan masyarakat dalam suatu majlis menunjukkan sikap persaudaraan dan persatuan yang kokoh; 4) kepatuhan dan ketundukan pada sang pemimpin tahlil merupakan pengamalan dari sila keempat; 5) persamaan tempat duduk, makanan dan tugas menunjukkan keadilan yang nyata di tengah-tengah masyarakat. Tahlilan di Kampung Sapen telah ada sejak tahun 1950an. Tahlilan bagi masyarakat Sapen berfungsi sebagai wadah silaturrahmi dan dakwah.
\end{abstract}

Kata Kunci: nilai-nilai Pancasila, tahlilan, Sapen

* Naskah diterima September 2021, direvisi Oktober 2021, dan disetujui untuk diterbitkan November 2021 


\section{A. Pendahuluan}

Pancasila merupakan dasar negara Indonesia yang mampu menyatukan bangsa yang majemuk. Ia telah menjadi falsafah hidup dan kepribadian bangsa Indonesia yang mengandung nilai-nilai dan normanorma luhur dan diyakini paling benar, paling adil, paling bijaksana, dan paling cocok dalam menyatukan bangsa Indonesia (Kaelan, 1996). Pancasila sebagai pedoman dan ideologi bangsa dalam bernegara diharapkan dapat menjelma pada setiap lini kehidupan masyarakat. Demikian juga, setiap perilaku rakyat hendaknya mengacu pada nilai-nilai dan norma-norma yang telah tertuang dalam sila-sila Pancasila. Semangat Pancasila hendaknya bisa menanamkan sifat patriotisme dan nasionalisme pada setiap individu bangsa, demi terciptanya bangsa yang kokoh dan mewujudkan cita-cita luhur bangsa ini.

Salah satu alasan mengapa Pancasila dijadikan dasar negeri ini, di antaranya sebagaimana yang disampaikan oleh Soekarno bahwa kebudayaan Indonesia merupakan kandungan Pancasila yang dilahirkan. Atau dengan istilah lain, Pancasila adalah saripati yang bersumber dari kebudayaan asli Indonesia (Hadi, 1994). Oleh karenanya, banyak budaya-budaya dan tradisi masyarakat terdahulu yang menjadi cerminan nilai-nilai Pancasila di dalamnya, salah satunya adalah tradisi tahlilan di kalangan umat Islam.

Tahlilan sendiri bukan termasuk syari'at Islam yang berasal dari daerah asal munculnya agama ini (Arab). Banyak peneliti yang mengatakan bahwa tradisi tahlilan merupakan hasil akulturasi dari 3 kebudayaan lama di Nusantara, HinduBuddha, Jawa, dan Islam Sebagaimana diketahui bahwa dalam tradisi tahlilan dalam budaya masyarakat Jawa terdapat penentuan perhitungan hari-hari tertentu dan pembakaran kemenyan atau dupa yang masih sarat dengan budaya Hindu-Buddha dan tradisi Jawa Kuno. Sedangkan unsur Islam terlihat dengan bacaan-bacaan Alquran dan kalimat-kalimat thayyibah (Khalil, 2008). Hadirnya Islam ke tanah Jawa telah memodifikasi keyakinan yang telah mapan sebelumnya, seperti animisme, dinamisme dan Hindu-Buddha. Hal itu disebabkan oleh sifat keterbukaan masyarakat Jawa terhadap agama dan tradisi baru yang membawa harapan dan kesejahteraan hidup yang lebih tinggi.

Seiring perkembangan zaman tahlilan tetap eksis di kalangan masyarakat Nusantara khususnya di Jawa. Meskipun ada beberapa yang berpendapat bahwa tahlilan itu bid'ah, namun mayoritas penduduk Indonesia masih tetap melakukan budaya lokal ini. Namun, menurut Robi Sugara bahwa sesuatu yang baru tidak dapat sewenang-wenang diklaim sebagai bid'ah sedangkan hal tersebut masih berstatus mudhathah. KH. Hasyim Asy'ari menegaskan bahwa tidak semua hal baru dalam agama itu sesat. Imam Syafi'i menyebutkan bahwa sesuatu yang baru yang tidak pernah dilakukan oleh Nabi saw dan salafus sholeh tidak semuanya sesat selama tidak berlawanan dengan Alquran dan Sunnah (Sugara, 2017).

Peneliti memilih studi kasus di Kampung Sapen Kelurahan Demangan Kecamatan Gondokusuman Yogyakarta sebagai objek penelitian ini. Hal itu disebabkan karena adanya beberapa pandangan dari masyarakat umum (luar kampung Sapen atau pendatang) yang memandang bahwa Yogyakarta sebagai pusat dan tempat kelahiran Organisasi Muhammadiyah tidak melakukan upacara atau tradisi tahlilan ini (Riskasari, 2018).

Atas dasar anggapan yang keliru itu, peneliti akan mencoba mengulas beberapa hal terkait tradisi tahlilan yang berlangsung di Sapen, baik dari aspek sejarah, pelaksanaan dan bagaimana nilai-nilai Pancasila yang tertuang dalam tradisi tersebut. Dengan tujuan untuk membantah anggapan miring bahwa Muhammadiyah tidak melakukan tahlilan, serta memaparkan representasi nilai-nilai Pancasila yang terkandung dalam tradisi tahlilan itu sendiri. Materi tahlilan bukanlah materi baru yang pernah diteliti. Ada banyak buku-buku, makalah-makalah, dan karya ilmiyah yang membahas tentang tema ini. Di antaranya adalah penelitian yang 
dilakukan Rhoni Rodin dengan judul "Tradisi Tahlilan dan Yasinan" (Rhodin, 2013). Penelitian ini membahas tentang konsep Islam dalam memandang tradisi yasin dan tahlilan yang berkembang di tengah-tengah masyarakat, serta mengungkap nilai-nilai yang terkandung dalam tradisi tersebut. penelitian ini menghasilkan bahwa tradisi tahlilan dan yasinan mengandung nilai-nilai yang dapat mendorong harmonisasi kehidupan sosial dan kebudayaan setempat.

Penelitian lain yang mengkaji tentang tradisi tahlilan sebagaimana dilakukan oleh Muhammad Diak Udin " Analisis Perilaku Sosial Masyarakat Dusun Plosorejo Desa Kemaduh Kab. Nganjuk dalam tradisi "tahlilan" studi deskriptif dengan menggunakan pendekatan pertukaran sosial (Udin, 2015). Kesimpulan dari penelitian ini yaitu bahwa perilaku masyarakat di dusun Polirejo memiliki perilaku sosial dalam tradisi tahlilan terbagi menjadi dua. Satu golongan yang puas dengan tradisi tahlilan dan sebagian kelompok lainnya tidak puas dan mengabaikannya dengan alasan ketidakseimbangan antara pengorbanan yang dikeluarkan dan bentuk penghargaan yang diterima.

Adapun penelitian yang menggunakan teori nilai-nilai Pancasila dalam kebudayaan masyarakat yaitu sebagaimana dilakukan oleh Jamilah, dkk. (2016) dengan judul "Studi Tentang Nilai-Nilai Pancasila Yang Terkandung dalam Tradisi Bakar Tongkang Masyarakat Tionghoa Kecamatan Bangko Bagansiapiapi Kabupaten Rokan Hilir". Jamilah, dkk mencoba untuk membuktikan adanya nilai-nilai Pancasila dalam tradisi Bakar Tongkang di dusun tersebut. Maka penelitian ini berkesimpulan bahwa dalam tradisi bakar tongkang ini memang ada nilai-nilai Pancasila yang terkandung di dalamnya. Hal itu dibuktikan melalui jawaban responden yang menyatakan bahwa $89,5 \%$ dari masyarakat di sana menjawab adanya nilai-nilai Pancasila yang terkandung dalam tradisi tersebut.

Sedangkan penelitian ini bertujuan untuk mengeksplorasi nilai-nilai Pancasila dalam tradisi tahlilan di Kampung Sapen. Hasil penelitian ini diarapkan dapat memberikan pengetahuan baik secara teoritis maupun praktis.

\section{B. Metode Penelitian}

Penelitian ini termasuk jenis penelitian kualitatif dengan sasaran suatu kasus penelitian budaya (studikasus) yang bersifat deskriptif dimana data disajikan dengan tertulis tidak berupa statistik. Hal ini sejalan dengan Moleong yang menyatakan bahwa penelitian kualitatif adalah penelitian yang menghasilkan prosedur analisis yang tidak menggunakan prosedur analisis statistik atau cara kuantifikasi lainnya (Moleong, 2015). Dalam penelitian ini penulis memaparkan gambaran mengenai situasi yang diteliti dalam bentuk uraian naratif.

Menurut Subroto, penelitian yang bersifat deskriptif mengharuskan penulis agar mencatat dengan teliti dan cermat semua data, baik yang berupa kata-kata, kalimat-kalimat, wacana, gambar, atau video (Subroto, 1992). Adapun tujuan dari penelitian kualitatif yang bersifat deskriptif adalah untuk memahami dan memaparkan fenomena budaya yang tersembunyi atau sedikit diketahui orang banyak.

Teknik mengumpulan data yang digunakan dalam penelitian ini adalah teknik wawancara dan observasi partisipan. Metode ini dipilih peneliti untuk bisa menguak secara mendalam hal-hal yang berkaitan dengan tradisi tahlilan di Sapen. Peneliti menggunakan pedoman wawancara dan membuat catatan etnografi. Peneliti melakukan partisipasi observasi di lokasi selama beberapa tahun mulai dari tahun 2016-2020. Untuk proses wawancara dilakukan dengan dua cara, yaitu secara langsung tatap muka dan tidak langsung atau melalui media $\mathrm{Hp}$.

\section{Hasil dan Pembahasan \\ 1. Potret Tradisi Tahlilan di Kampung Sapen}

Tahlilan sebagai anak kandung dari perkawinan antara agama Islam dan budaya lokal Nusantara khususnya Jawa sejatinya adalah bentuk transformasi dari upacara 
selamatan nenek moyang bangsa Indonesia yang mayoritas beragama Hindu-Buddha (Faizah, 2018). Selain itu, Lufaefi menyebutkan bahwa proses akulturasi budaya antara Hindu-Buddha dengan nilainilai keislaman dalam tahlilan tidak lepas dari peran walisongo (Lufaefi, 2018). Tahlilan merupakan bagian dari tradisi masyarakat Jawa yang telah mengakar kuat hingga saat ini. Hampir seluruh daerah di pulau Jawa mengenal dan masih mempraktikkan upacara tahlilan, bahkan di beberapa daerah luar Jawa, seperti di Jambi (Verliyanti, 2019), Pontianak (Supriadi et al., 2021), Sulawesi (Nasir, 2018).

Menyebarnya tradisi tahlilan secara masif ke seluruh penjuru Nusantara juga diuntungkan oleh masyarakat Indonesia yang plural. Sistem sosial plural menurut Geertz sangat berdampak pada peleburan beberapa budaya melalui proses akulturasi. Hal itu sebagaimana terjadi dalam tradisi tahlilan dimana terjadi proses perpaduan kebudayaan Hindu-Buddha, Islam dan kearifan lokal setempat (Greetz, 1993).

Kampung Sapen Kelurahan Demangan Kecamatan Gondokusuman Yogyakarta merupakan suatu daerah yang sampai saat ini aktif melakukan tradisi tahlilan. Kota ini terkenal di luar dengan kota/tempat lahirnya organisasi Muhammadiyah yang dibentuk oleh $\mathrm{KH}$. Ahmad Dahlan dan tidak melakukan tradisi tahlilan karena dianggap bid'ah. Namun kendati demikian, sebenarnya meskipun kulturnya mayoritas warga Muhammadiyah, namun ternyata mereka tetap menjalankan tahlilan.

Berdasar pada keterangan narasumber yang ada, terdapat beberapa pendapat terkait sejarah tahlilan di Sapen. Namun belum diketahui secara pasti tahun berapanya tahlilan mulai ada di Sapen. Hal itu dikarenakan masyarakat Sapen saat ini mayoritas dihuni oleh para pendatang dari daerah lain. Maka akan sulit mendapatkan sumber data yang valid terkait kapan awal pertama kali tradisi tahlilan ini diadakan di Sapen.

Menurut Janu Isnawan (2018), bahwa tahlilan di Sapen mulai gencar dilakukan sejak datangnya Asrori (pemuka agama setempat) ke Sapen, yaitu sekitar tahun 1977-an. Beliau merupakan salah satu mahasiswa perguruan tinggi di Jogja asal Rembang. Mula-mula dia aktif di remaja masjid Safinaturrahmah Sapen, lalu seiring perkembangan masa, ia mulai mengajak para pemuda asli Kampung Sapen untuk ikut serta dalam kegiatan tahlilan. Meski pada mulanya masih didominasi para mahasiswa pendatang, namun seiring berjalannya waktu semakin banyak penduduk asli Sapen yang mulai mengikuti kegiatan tahlilan.

Namun pendapat di atas dibantah oleh pendapat sesepuh warga asli Sapen, $\mathrm{H}$. Syufa'at Mansyur (2018). Beliau mulai tinggal di Sapen sejak tahun 1957. Menurutnya, tahlilan di Sapen sudah ada sejak dia pertama tinggal di Sapen. Tradisi tahlilan ini memang telah sering dilakukan oleh warga yang mengalami musibah kematian. Biasanya dipimpin oleh Pak Kaum yaitu dengan membacakan doa bersama untuk sang mayit. Menguatkan pendapat yang kedua, Asrori (2019), selaku ketua Kaum Sapen yang sekarang, mengatakan bahwa sejak dia datang pertama kali ke Jogja pada tahun 1977, tahlilan memang sudah ada di Sapen. Berdasarkan beberapa pendapat di atas, dapat diketahui bahwa tradisi tahlilan di Sapen sudah berjalan sejak rentang waktu 1950-an.

Tahlilan sering diartikan sama dengan slametan dan kenduri. Slametan atau kenduri dalam Ensiklopedi Kebudayaan Jawa diartikan sebagai upacara sedekah makanan karena seseorang telah mendapatkan anugerah atau kesuksesan sesuai apa yang dicita-citakan (dalam Sholikhin, 2002: 58). Sementara Geertz mengartikan slametan atau kenduri sebagai sebuah ritual yang dimaksudkan untuk merayakan, mendoakan, dan memperingati kejadiankejadian tertentu seperti, kelahiran, pernikahan, kematian, perayaan hari-hari besar, atau untuk acara-acara tertentu sesuai hajat orang yang mengadakannya (Geertz, 2013). Adapun tahlilan sebagai salah satu dari bagian dari slametan atau kenduri diartikan dengan upacara atau sebuah event 
yang di dalamnya terdapat pembacaan ayatayat Alquran dan kalimat-kalimat thayyibah dan doa lainnya yang dikhususkan untuk orang yang sudah meninggal (Humaidi et al., 2021).

Berdasar pengamatan penulis, umumnya acara tahlilan di kampung Sapen diadakan pada malam hari, namun ada juga yang diadakan di siang hari dengan alasan benturan kegiatan lain pada malam harinya. Pelaksanaan tahlilan dihadiri oleh sanak keluarga, tetangga RT setempat, dan beberapa jama'ah masjid. Diawali dengan sambutan oleh tuan rumah menggunakan bahasa Jawa Kromo, guna menyampaikan ucapan terima kasih, permohonan maaf serta mengutarakan maksud dan tujuan dari tahlilan yang akan digelar pada saat itu. Selanjutnya dilanjutkan oleh seorang Kaum (pemuka agama) untuk memimpin acara tahlilan yang terdiri dari pembacaan surat Yasin dan rangkaian bacaan tahlil lainnya.

Setelah pembacaan yasin-tahlil usai, hidanganpun dikeluarkan, mulai dari minuman teh/kopi, dan makanan berat berupa prasmanan. Namun, suguhan prasmanan ini hanya dilakukan oleh beberapa keluarga tergolong mampu. Setelah semua minuman dan makanan terbagi rata, maka para tamu dipersilahkan untuk menyantap makanan yang ada. Tidak lama setelah itu dibagikan berkat (bingkisan) yang berisi makanan untuk dibawa pulang. Isi berkat itu sendiri menyesuaikan momen peringatannya, jika itu hanya peringatan 3 atau 7 hari kematian sang almarhum biasanya isi berkatnya berupa bahan makanan mentahan meliputi beras seperempat kilogram, dua butir telor ayam, satu sashet minyak goreng, dua bungkus mie instan, dan gula satu ons. Berbeda ketika sudah menginjak peringatan ke-40 hari, 100 hari sampai 1000 harinya. Umumnya berkat yang diberikan sewaktu acara tahlilan berisi makanan siap saji atau siap santap, dan ada juga yang menambahinya dengan bungkusan snack lagi.

Secara umum, pelaksanaan tahlilan di kampung Sapen tidak jauh berbeda dengan tahlilan di daerah-daerah lainnya. Kendati demikian, terdapat perbedaan kecil dalam pelaksanaan tahlilan di Sapen, baik dari segi bacaan, suguhan, dan peserta yang hadir. Dari segi bacaan, tahlilan di Sapen cenderung lebih pendek jika dibandingkan dengan bacaan tahlilan di daerah yang mayoritas warga NU. Hal itu disebabkan oleh kondisi masyarakat perkotaan yang cenderung memiliki kesibukan lebih dibanding masyarakat pedesaan.

Dari segi suguhan, telah dijelaskan pada paragraf sebelumnya, bahwa suguhan atau berkat tahlilan di Sapen cenderung lebih simpel dan berupa sembako instan yang dibeli di toko. Sementara untuk tahlilan di pedesaan umumnya masih berupa makanan/jajanan hasil masakan rumahan dan berkatnya masih diwadahi wadah dari anyaman bambu/besek (Riskasari, 2018: 200).

Berdasarkan hasil observasi penulis selama mengikuti beberapa tahlilan di kampung Sapen, menunjukkan bahwa yang menarik dari tradisi tahlilan di Sapen adalah peserta yang hadir. Jika di daerah pedesaan tahlilan dihadiri oleh keluarga dan tetangga yang muslim, maka di Sapen terdapat keikutsertaan mahasiswa yang tergolong orang asing, tidak memiliki ikatan keluarga bahkan tidak pernah kenal dengan sang almarhum. Mahasiswa yang hadir dalam acara tahlilan biasanya adalah mereka yang kebetulan indekos di tempat tahlilan, sehingga tuan kos mengajak mereka untuk ikut di dalamnya. Atau karena diajak oleh pengurus takmir masjid. Perlu dimaklumi juga, bahwa ketika suatu keluarga ingin mengadakan tahlilan, untuk mendapatkan peserta, mereka membuat undangan untuk tetangga se RT, dan meminta bantuan kepada pengurus takmir masjid untuk mengajak 10-25 jamaah ikut dalam acara tahlilan tersebut.

Alasan keikutsertaan mahasiswa dalam tradisi tahlilan di Sapen berdasarkan pengakuan dari Zayadi dan Heri Fadli (2018) didasari pada keinginan untuk berbaur bersama masyarakat asli Sapen dan karena faktor berkat yang menggiurkan. Di samping itu, ajakan marbot masjid yang merupakan seorang mahasiswa pendatang juga berperan penting atas keterlibatan mahasiswa atau anak kos dalam kegiatan 
tahlilan di kampung Sapen. Berdasar pengamatan peneliti, biasanya undangan tahlilan akan diberikan kepada beberapa tetangga terdekat dan kepada marbot masjid. Undangan yang diberikan kepada marbot masjid berisi keterangan " + 15-25 jamaah masjid", atau dengan kata lain, sang marbot diminta untuk mengajak beberapa jamaah masjid yang berkenan mengikuti tahlilan, dan di dalamnya termasuk mahasiswa.

Selain mahasiswa, dalam beberapa kasus, ternyata ada jamaah non-muslim yang juga turut serta dalam tahlilan di Sapen. Hal itu sebagaimana dituturkan oleh Amin Sujadmiko (2020), salah satu petugas "bunga selasih". Menurutnya, biasanya kehadiran warga non-muslim pada acara tahlilan di Sapen terjadi pada keluarga yang dahulunya beragama selain Islam, atau pada mereka yang kenal baik dengan sang almarhum. Maka sebagai bentuk penghormatan dan dorongan rasa kemanusiaan yang tinggi di antara warga, mereka dengan senang hati ikut serta hadir meramaikan acara tahlilan, meskipun mereka tidak ikut dalam pembacaan surat yasin maupun doa-doa lainnya.

\section{Makna, Hakekat, dan Nilai-Nilai Pancasila}

Secara etimologi Pancasila berasal dari bahasa Sansakerta, yaitu "Panca" yang berarti "Lima", dan "sila" yang berarti "dasar". Jadi secara harfiah Pancasila diartikan sebagai lima dasar. Lalu secara terminologi Pancasila diartikan sebagai dasar negara Indonesia dan falsafah hidup bangsa Indonesia yang lahir dari hasil kesepakatan dan perenungan yang mendalam dari para tokoh pendiri negeri ini (Bakry, 1997).

Pancasila sebagai dasar negara dalam artian, Pancasila selain sebagai landasan yang mempunyai kekuatan yuridis konstitusional, ia juga memiliki peran sebagai landasan ideologi yang harus mampu memberikan orientasi, wawasan, asas, dan pedoman yang normatif dalam seluruh bidang kehidupan bangsa (Poespowardojo, 1989).
Pancasila sebagai ideologi negara telah dirumuskan oleh para tokoh kenegaraan pada sidang BPUPKI dilanjutkan pada sidang PPKI. Dengan demikian nilai-nilai Pancasila diharapkan tetap kekal dan terpancar dalam kehidupan berbangsa dan bernegara penduduk Indonesia. Hal itu sebagaimana tersirat dalam pembukaan UUD 1945 dan dijelmakan dalam pasalpasal UUD 1945 (Poespowardojo, 1989).

Adapun nilai-nilai yang terkandung dalam tiap-tiap sila Pancasila antara lain:

a. Nilai Ketuhanan

Ketuhanan dalam makna yang lebih luas adalah sebuah keyakinan dan pengakuan yang diekspresikan dalam bentuk perbuatan terhadap Dzat yang Maha Kuasa sebagai Pencipta. Nilai ketuhanan sendiri bisa diekspresikan dengan cara taat melakukan ibadah, menciptakan sikap toleransi dan menjalin hubungan yang harmonis antar pemeluk agama, baik dalam satu agama atau lintas agama (Hadi, 1994).

b. Nilai Kemanusiaan, Keadilan, dan Adab Budi Pekerti

Manusia sebagai makhluk ciptaan Tuhan Yanga Maha Esa haruslah meyakini bahwa di atas orang yang paling kuat di dunia ini masih ada yang lebih kuat, yaitu Dzat yang menciptakaannya. Oleh karena itu manusia sering kali didefinisikan sebagai hewan yang berfikir. Mengapa demikian, karena ciri utama yang dapat membedakan manusia dengan hewan dan makhlukmakhluk lainnya adalah akal pikiran mereka. Maka seharusnya sebagai manusia seharusnya kita memikirkan perbuatan mana yang baik dilakukan dan mana yang buruk (Hadi, 1994).

c. Nilai Persatuan

Salah satu kekuatan besar yang dimiliki bangsa ini adalah keinginan untuk bersatu. Indonesia yang terdiri dari banyak suku dan ragam budayanya telah mampu membangun suatu negara yang besar. Hal itu tidak lepas dari semboyan bangsa ini yang terpampang dalam lambang negara Bhinneka Tunggal Ika.

Semangat persatuan ini haruslah tetap terjaga dan terpatri dalam kehidupan sosial bangsa ini. Bangsa Indonesia adalah satu, 
satu tanah air, satu bahasa dan satu semangat dalam menciptakan persaudaraan yang kokoh. Maka negara haruslah tampil dalam mengatasi segala problematika paham antar suku, budaya dan agama dengan menanamkan semangat nasionalisme yang religius berdasar tekad yang bulat dan cita-cita bersama (Poespowardojo, 1989).

d. Nilai Kerakyatan dan

Permusyawaratan

Nilai yang terkandung dalam sila ke empat ini menunjukkan bahwa negara kita memegang asas kedaulatan rakyat atau demokrasi. Dalam hal ini Indonesia mengaplikasikan nilai demokrasi dalam pemerintahannya dan dikenal sebagai pemerintahan perwakilan, yaitu suatu pemerintahan yang dilakukan oleh orangorang yang telah dipilih oleh rakyat dan diberi kuasa untuk memerintah mereka (Hadi, 1994).

Selain dari pada itu, asas permusyawaratan dan asas mufakat juga tak kalah pentingnya. Setiap perkara dan permasalahan yang terjadi di tengah-tengah kehidupan masyarakat haruslah diselesaikan dengan cara musyawarah yang dipimpin oleh akal sehat dan rasa tanggung jawab yang tingi kepada Tuhan Yang Maha Esa dan kepada rakyat yang diwakilkannya, demi menghasilkan kata mufakat (Hadi, 1994).

e. Nilai Keadilan Sosial

Nilai keadilan ini akan tercapai bilamana keempat nilai-nilai sebelumnya telah terlaksana dengan baik. Karena mustahil akan mencapai makna adil bila segala sesuatunya tidak dilandaskan pada nilai Ketuhanan, kemanusiaan, persatuan dan kerakyatan yang berdaulat. Keadilan sosial yang dimaksudkan adalah keadilan yang berlaku bagi masyarakat dalam segala bidang kehidupan baik material maupun spiritual. Dengan artian keadilan tidak hanya untuk orang kaya saja atau para pemimpin dan pejabat saja, namun orang miskin dan rakyat jelata lainnya juga berhak mendapatkan keadilan.

Salah satu bentuk pengamalan dari sila kelima ini yaitu dengan menjaga antara hak dan kewajiban, saling menolong, menghargai hasil karya orang lain, memupuk sifat bekerja keras, bersikap solider, dan mendahulukan kepentingan umum di atas kepentingan pribadi atau golongan (Hadi, 1994).

3. Aktualisasi Nilai-Nilai Pancasila dalam Tradisi Tahlilan di Kampung Sapen

Adapun nilai-nilai Pancasila yang tertuang dalam tradisi tahlilan di Sapen antara lain sebagai berikut:

Pertama, Nilai Ketuhanan. Tahlilan sebagai tradisi yang dibawa oleh wali songo dengan muatan agamanya telah cukup mewakili pengamalan dari sila yang pertama (Rohman, 2019). Dengan mendoakan orang yang telah meninggal, otomatis akan menstimulus pikiran bahwa Tuhan Maha Menghidupkan dan Maha Mematikan. Kesadaran akan keniscayaan mati akan sangat terasa ketika kita mengetahui saudara atau kerabat kita meninggal. Dan dari ingat mati akan terdorog motivasi untuk bertaubat dan beribadah dengan sebenar-benarnya untuk bekal kita nanti di alam setelah dunia ini (wawancara dengan Janu Isnawan).

Disamping itu, sikap keterbukaan untuk menjalin hubungan antar warga asli Sapen dan pendatang melalui tahlilan telah menunjukkan pengamalan nilai ketuhanan yang tinggi. Juga ditambah dengan sikap toleransi kepada sesama pemeluk agama baik sesama muslim atau bahkan dengan nonmuslim sebagaimana dalam tradisi kenduri (wawancara dengan Zayadi).

Kedua, nilai kemanusiaan. Di antara nilai-nilai kemanusiaan yang terkandung dalam tradisi tahlilan di Sapen yaitu sikap saling berbela sungkawa atas kematian sang almarhum, berusaha menghibur para ahli waris dengan ikut menghadiri tahlilan di rumahnya sehingga keluarga yang ditinggalkan tidak merasa kesepian. Hal itu menunjukkan simpati terhadap keluarga yang berduka (wawancara dengan Qomari Zaman. Ketua RW. 08).

Selain itu, penyambutan yang hangat dari tuan rumah disertai senyuman yang menunjukkan sikap saling menghargai dan menghormati antarsesama manusia. Dan itu 
semua sudah mewakili pengamalan dari nilai sila kedua dari pancasila yaitu kemanusiaan yang adil dan beradab.

Ketiga, nilai persatuan. Menurut $\mathrm{H}$. Asrori, tahlilan adalah cermin dari persatuan bangsa. tahlilan adalah sarana guyup warga yang paling ampuh. Menurutnya, tahlilan telah mampu menyatukan si kaya dan si miskin, seorang pejabat dan seorang buruh, dosen dengan mahasiswanya, bahkan menyatukan orangorang dari berbagai daerah dalam satu majelis (Wawancara dengan Bapak H. Asrori, MA. kepala Kaum Sapen sekarang). Dengan satu tekad dan tujuan yang sama semua warga berkumpul untuk bersamasama mendoakan si almarhum agar bisa diterima di sisi Allah dengan husnul khatimah.

Demikian juga halnya tahlilan mencerminkan asas ke-Bhinneka Tunggal Ika-an dengan menerima dan ikut mengundang para mahasiswa pendatang dari berbagai suku, daerah, dan budaya yang beragam. Ini selaras pula dengan konsep ajaran Islam yang tertuang dalam surat Al-Hujurat ayat 13 yang mengatakan bahwa keberagaman penciptaan manusia bersuku-suku dan berbangsa-bangsa adalah untuk saling mengenal.

Keempat, nilai Kerakyatan dan Permusyawaratan. Sebagaimana diketahui bersama bahwa tahlilan berlangsung di tengah-tengah masyarakat. Dengan melibatkan beberapa unsur dari lapisan masyarakat yang termasuk di dalamnya seorang kepala Kaum yang telah disetujui dan disepakati bersama untuk memimpin pelaksanaan tahlilan dari awal sampai akhir acara. Nilai sila keempat ini, sebagaimana tercermin dalam pelaksanaan tahlilan di kampung Sapen, dimana setiap anggota yang ikut dalam tahlilan haruslah mengikuti apa-apa yang dibaca pimpinan tahlil (Pak Kaum). Jika pimpinan membaca cepat maka, yang lain harus mengikuti membaca cepat bagitu juga sebaliknya, jika lambat maka yang lain juga harus ikut lambat. Tidak patut bila ada warga anggota tahlil karena ingin selesai dulu dalam bacaannya lantas ia membaca lebih cepat dari bacaan yang memimpin tahlil.

Secara tidak langsung, dalam pelaksanaan tahlilan di Sapen dan kemungkinan besar juga di berbagai tempat lainnya telah menerapkan konsep demokrasi terpimpin, yaitu dimana dalam prosesi tahlilan jamaah menyepakati perwakilan dari mereka (Pak Kaum) untuk menjadi pemimpin jalanya tahlilan dari awal hingga akhir. Kendati demikian, sesekali pimpinan tahlilan akan meminta pendapat kepada para jamaah atau tuan rumah, misalnya ketika hendak memulai biasanya Pak Kaum akan menanyakan kepada jamaah dan tuan rumah apakah tahlilan sudah bisa dimulai atau masih menunggu beberapa jamaah atau tamu undangan lainnya. Begitupun juga, sebelum jamaah dibubarkan, biasanya Pak Kaum akan memusyawarahkan kembali apakah masih ada yang mau disampaikan oleh tuan rumah.

Kelima, nilai Keadilan sosial. Dalam banyak bidang, mungkin keadilan semakin jarang kita temui. Namun beda halnya dengan tradisi tahlilan. Tahlilan memegang tinggi asas keadilan. Hal itu dibuktikan dari penempatan tempat duduk. Bisa dipastikan tidak ada perbedaan tempat duduk yang disediakan oleh tuan rumah untuk para undangan yang hadir. Semuanya duduk lesehan di atas tikar atau karpet yang sama. Tidak memandang di situ ada seorang kiai, pejabat, dosen, polisi, bahkan presiden pun bila ikut tahlilan akan duduk di bawah bersama dengan warga lainnya.

Ditambah dari segi makanan atau suguhan yang dihidangkan. Semua sama merata baik dari segi ukuran, jenis makanan, dan banyaknya. Tidak ada tingkatan makanan untuk undangan kelas ekonomi, kelas eksekutif, atau kelas VVIP. Dalam tahlilan khususnya di Sapen semua orang mendapatkan makanan dan berkat yang adil, baik yang warga asli ataupun yang mahasiswa pendatang. Oleh karena itu tidak ada ceritanya warga protes karena tempat duduknya disendirikan atau makanannya dibedakan dengan yang lainnya. Maka inilah sebenarnya bentuk pengamalan nilai keadilan sosial bagi seluruh rakyat Indonesia itu 
dipraktekkan di tengah-tengah masyarakat.

\section{Kesimpulan}

Tahlilan di Kampung Sapen telah ada sejak tahun 1950-an. Tahlilan bagi masyarakat Sapen berfungsi sebagai wadah silaturrahmi dan dakwah. Selain masyarakat, mahasiswa pendatang juga ikut merasakan manfaat dan keberkahan dari tahlilan. Disamping mereka dapat mengenal dan berbaur dengan masyarakat asli Sapen, mereka juga terlibat dalam melestarikan tradisi tahlilan serta merasakan harmoni kehidupan masyarakat Sapen melalui tradisi tahlilan.

Selain itu, melalui penelitian ini terhadap fenomena tradisi tahlilan di kampung Sapen membantah anggapan yang mengatakan bahwa warga Muhammadiyah tidak melaksanakan tahlilan. Hal ini sebagaimana telah direpresentasikan oleh warga Muhammadiyah di kampung Sapen yang tetap konsisten dalam melestarikan tradisi tahlilan.

Adapun nilai-nilai Pancasila yang terdapat dalam tradisi tahlilan di kampung Sapen yang selama ini diimplementasikan masyarakat setempat di antaranya ialah; 1) kesadaran teologi akan adanya Tuhan yang Maha Menciptakan dan Mematikan manusia dan seluruh makhlukmakhluknya, ini adalah pengamalan dari nilai ketuhanan; 2) adanya simpati pada keluarga yang berduka, dan doa bersama untuk meminta kebaikan untuk sang almarhum, adalah pengamalan sila kedua; 3) berkumpulnya semua lapisan masyarakat dalam suatu majlis menunjukkan sikap persaudaraan dan persatuan yang kokoh; 4) kepatuhan dan ketundukan pada sang pemimpin tahlil merupakan pengamalan dari sila keempat; 5) persamaan tempat duduk, makanan dan tugas menunjukkan keadilan yang nyata di tengah-tengah masyarakat.

\section{Ucapan Terima Kasih}

Dengan terbitnya tulisan ini, penulis mengucapkan terimakasih kepada beberapa pihak yang ikut serta memberikan dukungan serta saran yang konstruktif dalam menyelesaikan penelitian ini. Tidak lupa ucapan terimakasih kepada seluruh responden yang dengan ramah untuk meluangkan waktunya dalam memberikan data interview, khususnya Bapak H. Asrori, MA. (Pemuka agama di Sapen) dan masyarakat kampung Sapen pada umumnya.[]

\section{Daftar Pustaka}

Bakry, N. M. (1997). Orientasi Filsafat Pancasila. Liberty Yogyakarta.

Faizah, K. (2018). Kearifan Lokal TahlilanYasinan Dalam Dua Perspektif Menurut Muhammadiyah. Aklam: Journal of Islam and Plurality, 3(2), 213227.

Geertz, C. (2013). Agama Jawa: Abangan, santri, priyayi dalam kebudayaan Jawa. Komunitas Bambu.

Greetz. (1993). Kebudayaan dan Agama (2nd ed.). Kanisius.

Hadi, H. (1994). Hakekat \& Muatan Filsafat Pancasila, Kanisius. Kanisius.

Humaidi, Wahid, Wardani, D. J., Rohman, S., Husni, M., A'Yunnisa, Q., Meilynda, R., Lailatussiam, S., Islaha, Z., \& Anam, A. G. (2021). Tradisi Tahlilan: Potret Akulturasi Agama, Budaya Khas Islam Nusantara dan Tradisi NU. An Nahdhoh Jurnal Kajian Islam Aswaja, 1(1), 89-99.

Kaelan. (1996). Pendidikan Pancasila Yuridis Kenegaraan. Paradigma.

Khalil, A. (2008). Islam Jawa, Sufisme dalam Etika dan Tradisi Jawa. (U.-M. Press (ed.)).

Lufaefi. (2018). Reaktualisasi Dakwah Walisongo: Gerak Dakwah KH. Aqil Siraj dalam Menebar Islam Rahmatan Lil Alamin. Aqlam: Journal of Islam And Plurality, 3(1), 102-116.

Moleong, L. J. (2015). Metodologi Penelitian Kualitatif. PT Remaja Rosdakarya. 
Nasir, R. (2018). Tradisi Tahlilan dalam Kehidupan Masyarakat Kelurahan MonongkokiKecamatan Polongbangkeng Utara Kabupaten Takalar: Tinjauan Pendidikan Islam. Universitas Muhammadiyah Makassar.

Poespowardojo, S. (1989). Filsafat Pancasila. PT Gramedia Pustaka Utama.

Rhodin, R. (2013). Tradisi Tahlilan Dan Yasinan. IBDA: Jurnal Kajian Islam Dan Budaya, 11(1), 76-87.

Riskasari, A. (2018). Pengaru Persepsi Tradisi Tahlilan di Kalangan Masyarakat Muhammadiyah Terhadap Relasi Sosial di Desa Gulurejo Lendah Kulon Progo Yogyakarta. Panangkaran, 2(2), 189-205.

Rohman, N. F. (2019). Pembacaan Surat Yasin dalam Tradisi Tahlilan: Kajian Living Qur'an di Desa Palem Kecamatan Campurdarat. UIN Sultan Thaha Saifuddin.

Subroto, E. D. (1992). Pengantar Metode Penelitian Linguistik Struktural. Sebelas Maret University Press.
Sugara, R. (2017). Reinterpretasi Konsep Bid'ah dan Fleksibilitas Hukum Islam Menurut Hasyim Asy'ari. Asy-Syari'ah, 19(1), 37-48.

Supriadi, Zakso, A., \& Mirzachaerulsyah, E. (2021). Tradisi Religi dalam Ritual Yasinan-Tahlilan sebagai Upaya Pelestarian Kearifan Lokal Masyarakat Sukamulia Kota Pontianak. Jurnal Pendidikan Dan Pembelajaran Khatulistiwa, 10(6), 1-9.

Udin, M. D. (2015). Analisis Perilaku Sosial Masyarakat Dusun Plosorejo Desa Kemaduh Kab. Nganjuk dalam Tradisi Tahlilan. Tribakti: Jurnal Pemikiran Keislaman, 26(2).

Verliyanti, V. (2019). Makna Gebing Pada Tradisi Tahlilan Masyarakat Jawa di Desa Singkawang Kecamatan Muara Bulian Kabupaten Batanghari. UIN Sultan Thaha Saifuddin. 